\title{
A Study of the Perceptions of Teacher Trainees Towards the Two-Year Teacher Education Programme Being Run in India
}

\author{
Adit Gupta*, Ruchi Rakwal \\ MIER College of Education, Jammu, India \\ E-mail: adit@mier.in
}

\begin{abstract}
The present study assesses the perceptions of teacher trainees towards the two-year teacher education programme being run in Jammu (India). The Teacher Trainees Perceptions Assessment Questionnaire (TTPAQ) was developed by the researchers for achieving the objectives of the study. The questionnaire consisted of four scales namely, Duration, Pedagogical Aspects, Curriculum and Innovation. A sample of 200 students enrolled in the two-year B.Ed. and M.Ed. programmes of a private and Government college of education were chosen for the study. The results of the study showed that the TTPAQ was a reliable and valid instrument for assessing the perceptions of the teacher trainees towards the two-year teacher education programme. The mean scores of the different scales of the TTPAQ were high which indicated that teacher trainees of the B.Ed. and M.Ed. programmes had positive perceptions towards the duration, pedagogical aspects, curriculum and innovativeness of the programme. No gender differences were observed in the results of the study. Significant differences were observed between the students of private and government colleges and also between the teacher trainees of B.Ed. and M.Ed. classes on all the four scales of the TTPAQ. This research study happens to be the first of its kind in this region that assesses the perceptions of teacher trainees due to a sudden stretch in the duration of M.Ed. and B.Ed. programmes from one to two years.
\end{abstract}

Keywords: perceptions of teacher trainees, two years B.Ed. and M.Ed. programmes

\section{Introduction}

The Teacher Education Policy in India has evolved over time and is based on recommendations contained in various Reports of Committees/Commissions on Education, the important ones being the National Policy of Education (NPE,1986) which reflects this commitment by considering pre-service and in-service teacher education as a continuous process and two ends of a continuum ${ }^{[1]}$. An analysis of the recommendations of various commissions, committees and the education policy of India reveals that the primary effort of the policy planners was to bring qualitative improvement in teacher education system along with quantitative expansion of the facilities for teacher training. Efforts have been made to change the teacher education curricula according to the contextual needs of emerging society and break the isolation of teacher education institutions. In fact, the first two decades of the post-independence period were characterized by significant efforts to break away from the colonial legacy and modernize the teacher education curriculum along with the school curriculum. The concern for quality improvement and indigenization of teacher education had been the top priority of educational planners which is reflected in the concerns appointed by the government of India from time to time since independence. The University Education Commission (1948), Secondary Education Commission (1953), Chattopadhyay Committee Report (1983-85), Acharya Ramamurthy Commission (1990) and several seminars and study groups that were set up to discuss improvements in elementary and secondary teacher education, from time to time expressed concern over the poor quality of teacher education, and its isolation from, both the mainstream of university life, and the ground realities of schools. These commissions stressed on the need for flexibility, and local specificity; and strongly felt, that the whole teacher education programme needs to be remodelled to strike more balance between the theory and practice, and assessment of teacher trainees' performance.

One of the important landmarks in the history of Indian efforts towards bringing qualitative improvement in education in general, and teacher education in particular is the recommendations of Education Commission (1964-66) popularly known as the Kothari Commission. This was the first commission in the post-independent India, which comprehensively 
dealt with all stages of education, from pre-primary to higher level, including vocational and technical education. The commission stated, "the essence of the programme of teacher education is quality and, in its absence, teacher education becomes, not only a financial wastage but a source of overall deterioration in educational standards" ${ }^{[2]}$.

For pre-service training, the National Council of Teacher Education (NCTE), a statutory body of the Central Government, is responsible for planned and coordinated development of teacher education in the country. The NCTE lays down norms and standards for various teacher education courses, minimum qualifications for teacher educators, course and content and duration and minimum qualification for entry of student-teachers for the various courses. It also grants recognition to institutions (government, government-aided and self-financing) interested in undertaking such courses and has in-built mechanism to regulate and monitor their standards and quality. The Justice Verma Commission (JVC) appointed by the Government of India at the behest of the Hon'ble Supreme Court of India, submitted its report in 2012. The Commission made several recommendations for revamping the system of teacher education in the country, such as introducing integrated teacher education programs of longer duration, enhancing the duration of existing teacher education programs and upgrading the status of teacher education by making it a part of the higher education system in India. The Commission also recommended to establish inter-university centres of teacher education to ensure continuing professional development of teacher educators, re-orientation of teacher education curriculum to enhance the quality of teacher preparation, strengthen the regulatory and monitoring mechanisms and establishment of performance appraisal system for teacher education institutions, teacher educators and school teachers. Thus, the Commission presented a holistic vision of teacher education in the country from the perspective of quality as well as regulation. To translate the vision of JVC into reality, the National Council for Teacher Education (NCTE, 2014) revisited its regulations, norms and standards for various teacher education programs and notified new regulations on $1^{\text {st }}$ December 2014. As per the regulations the duration of the B.Ed. and M.Ed. programmes was enhanced from one year to two years ${ }^{[3]}$.

Thus, the main purpose of this study was to assess the perceptions of the students towards the newly introduced twoyears teacher education programme at the B.Ed. and the M.Ed. levels and how this increase in duration has impacted the students in general.

\section{Review of related literature}

Pillai ${ }^{[4]}$ studied the impact of practicing schools on the quality of teaching practice of teacher trainees. The objectives of the study were: (1) to identify the facilities available in the practicing schools; (2) to see if there is any influence of guide teachers on the performance of teacher trainees; (3) to assess the quality of performance of the teacher trainees during the practice teaching session; and (4) to see whether there is any impact of facilities available in the practicing schools on the quality of performance of the teacher trainees. Findings revealed that (1) $37.5 \%$ of the selected practicing schools provided sufficient facilities for teacher trainees. The facility was low or poor in $50 \%$ of the schools, (2) all the guide teachers in the practicing schools were interested in guiding the teacher trainees, (3) the teaching practice of teacher trainees was satisfactory only in $31.3 \%$ of schools. In more than $40 \%$ of the schools, the teaching practice was not satisfactory, (4) the facilities available in practicing schools played a significant role in improving the quality of teaching practice of teacher trainees.

Gopinathan ${ }^{[5]}$ reported that while considerable attention is being paid to reforming the education system to prepare students for the challenges of globalization and a knowledge-based economy, teacher education models in the Asia Pacific remain insufficiently critiqued. There is an urgent need to rethink teacher education as, in spite of decades of investment and development, major problems of inequality, attrition, incomplete and inadequate learning continue to blight our education systems. It was proposed that teacher education needs to become more culturally authentic as teaching and learning are best viewed as culturally scripted activities. The utilization of indigenous knowledge will be central to this task. The article concluded with some suggestions for how the task may be started.

Halakatti and Mundasnavar ${ }^{[6]}$ reported that education lays foundation of our future citizens, civilization and our society at large. The concept of learning throughout life is emerging as one of the key aspects of the 21st century learning. It has a key role in formulating and achieving a future vision. Teaching is an important aspect of the educational system. Teachers are the torch bearers in achieving social cohesion, national integration and a learning society. They not only disseminate knowledge but also create and generate new knowledge. The National Policy on Education, 1986, stipulates that teacher education is a continuous process and its Pre-service and In-service components are inseparable. Professional development of teachers begins with Pre-service and gets renewed through In-service programs. The teachers should be well versed with the latest developments in their field. Therefore, it is necessary that continuous training should 
be provided to teachers of higher education throughout their career to keep them abreast of the new knowledge and information in the field of education.

Kalra and Baveja ${ }^{[7]}$ studied the student teachers' thinking about knowledge learners in India. Prospective teachers enter classrooms that are not very different from those that they have attended as students. During their School Experience Program (SEP), they often behave like their teachers did. The thinking and beliefs of pre-service teachers should be a focus of dialogue in teacher education programmes. Teachers need to reflect on and evaluate their own thinking and beliefs and at times the metaphors they use in their classrooms. They need to begin to assess their own practice and to reflect upon how these influence their perceptions and decisions within their own classrooms, keeping in view the 'text book culture' prevalent in India this paper explores and analyses the thinking of teachers about 'knowledge', learning and 'learners' and its implications in the Indian scenario.

Sao and Behera ${ }^{[8]}$ studied the student-teachers attitude towards two-year B.Ed. programme with special reference to NCTE New Regulation, 2014 in Purulia district of West Bengal. 260 student-teachers of one Govt. Sponsored (57) and three Self Financing / Private (203) B.Ed. Colleges (both Urban and Rural areas) affiliated to Sidho-KanhoBirsha University in Purulia District of West Bengal were taken as representative sample of the whole population. The study revealed that the attitude of B.Ed. Student-Teachers in Purulia District of West Bengal is neither favourable nor unfavourable towards two-year B.Ed. Programme i.e., they show satisfactory or average attitude towards two-Year B.Ed. Programme. The study also revealed that male and female, Pre-service and In-service, as well as less than 5 years and above 5 years teaching experience student-teachers attitude towards two-year B.Ed. programme did not differ significantly. On the other hand, rural and urban as well as Govt. and Private B.Ed. college student-teachers attitude towards two-year B.Ed. programme differs significantly.

Khan ${ }^{[9]}$ conducted a research to find out the B.Ed. students and teacher educator experiences in two-year B.Ed. programme through an empirical investigation of 37 teacher educators teaching the B.Ed. course and 110 student teachers enrolled in the B.Ed. course. The researcher utilized two self-constructed scales to do so. The results showed that both the hypotheses and the sub hypotheses were rejected showing more unfavourable experiences of B.Ed. students and teacher educators in two-year B.Ed. programme than favourable experiences. However, a number of them had moderate experiences as well. Further it was evident from the results of separate dimensions that B.Ed. students had least favourable experiences in implementation of curricular activities. As the extended program provides a wide range of curricular activities, it might be an indication that it didn't suite them or institution was unable to provide proper facilities. Also, they have the highest unfavourable experience for the internship programme.

The current research would add to the richness of existing studies in the field of teacher education especially with regards to the change in structure of the teacher education programmes, its duration, pedagogical and innovative aspects of the curriculum etc.

\section{Objectives of the study}

The specific objectives of the study are:

(1) To find out the reliability and validity of the Teacher Trainees Perceptions Assessment Questionnaire (TTPAQ).

(2) To assess the perceptions of teacher trainees towards the two-year teacher education programme in terms of Duration, Pedagogy, Curriculum and Innovation.

(3) To investigate whether gender differences exist in the perceptions of teacher trainees towards the two-year teacher education programme .

(4) To investigate whether differences exist in the perceptions of teacher trainees towards the two-year teacher education programme between private and government colleges of education.

(5) To investigate whether differences exist in the perceptions of teacher trainees towards the-two-year teacher education programme between B.Ed. and M.Ed. courses.

\section{Sample of the study}

The study was conducted using a Descriptive Survey Method. The sample for the study consisted of teacher trainees from two colleges of education i.e. one private and one government college of education. 200 teacher trainees took part in the study and the selection of students was done using random sampling. The sample was chosen carefully so as to be representative of the population and comprise of coeducational classes in order to permit an unbiased test of gender differences. All the students who were a part of the sample were in the $4^{\text {th }}$ Semester of the B.Ed. and M.Ed. course and had 
sufficient exposure to the two-year teacher education programme to provide their actual perceptions about the course. In the total sample there were 148 Female teacher trainees and 52 Male teacher trainees. At the B.Ed. level there were 140 students and at the M.Ed. level there were 60 students. With regards to the colleges of education, there were 100 students each from the government and private college of education.

\section{Tool used}

For the purpose of the accomplishment of objectives a research tool was constructed, namely Teacher Trainees Perception Assessment Questionnaire (TTPAQ). The questionnaire consisted of four scales namely Duration, Pedagogical Aspects, Curriculum and Innovation. Each scale consisted of seven items. The TTPAQ measures teacher trainees' perceptions across the four scales. Responses to the items were scored 1, 2, 3, 4, 5 respectively, from Strongly Agree, Agree, Not Sure, Disagree and Strongly Disagree (Likert type scale).

The researchers also reviewed some other tools that were used by Sao and Behera ${ }^{[8]}$ and Khan ${ }^{[9]}$ to evaluate the two years B.Ed. programme. The main difference between these tools and the tool developed by the researchers was that the tool used in the present study attempts to assess the perceptions of the students with regards to four broad areas concerned with the change in duration of the teacher education programme from one year to two years duration. Whereas, the other two scales study the attitude of teacher trainees towards the two-year programme and their opinions i.e. favourable or unfavourable towards different aspects of the two-year teacher education programme. Since the scope of the present study was well defined, hence, the researchers developed a new tool from ground up for data collection and analysis.

\section{Results and findings}

The results of the study have been given objective wise in the following section:

\subsection{Research objective 1}

To assess the reliability and validity of the Teacher Trainees Perceptions Assessment Questionnaire (TTPAQ).

Two indices for scale reliability and validity were generated separately. The Cronbach alpha reliability coefficient was used as an index of scale internal consistency of the test items relative to other test items which are designed to measure the same construct of interest. A coefficient of 0.00 indicates a complete absence of a relationship, whereas 1.00 is the maximum possible coefficient that can be obtained ${ }^{[10]}$. A discriminant validity index (namely, mean correlation of a scale with other scales) was used as evidence that each TTPAQ scale measures a separate dimension that from the other scales in this questionnaire.

Table 1 illustrates the inter-correlations between the four scales of TTPAQ. It is evident that all the scales are positively correlated with each other and the inter-correlations are significant $(\mathrm{p}<0.001)$. This shows that all the scales of TTPAQ are in harmony with each other and will contribute to the study of perceptions of teacher trainees towards the twoyear B.Ed. and M.Ed. programmes.

\begin{tabular}{|c|c|c|c|c|}
\hline & duration & pedagogical aspects & curriculum & innovation \\
\hline duration & & $0.31^{* *}$ & $0.64^{* * *}$ & $0.29^{* * *}$ \\
\hline $\begin{array}{l}\text { pedagogical } \\
\text { aspects }\end{array}$ & & & $0.44^{* *}$ & $0.73^{* *}$ \\
\hline curriculum & & & & $0.39^{* * *}$ \\
\hline innovation & & & & \\
\hline
\end{tabular}

$\mathrm{N}=200 * *$ Correlation is significant at the 0.01 level

The results of the two statistical indices are reported in Table 2 . The scale reliability estimates for the different scales of the TTPAQ using the individual student as the unit of analysis ranged from 0.56 for the Duration scale to 0.80 for the Innovation scale and Pedagogical Aspects scale. Thus, in all above scales the reliability result of the TTPAQ were consistently above 0.50 . This suggested that TTPAQ could be used as a reliable tool ${ }^{[11]}$ with college students. The mean correlation for the four scales of the TTPAQ ranged from 0.41 for the Duration Scale to 0.49 for the Pedagogical Aspects and Curriculum scales (Table 2). This shows that TTPAQ is valid tool for assessing the perceptions towards two-year teacher education programmes. 
Table 2. Internal consistency reliability (cronbach alpha coefficient), discriminant validity (mean correlation with other scales) for TTPAQ

\begin{tabular}{cccc}
\hline scale name & no. of items & alpha reliability & $\begin{array}{c}\text { mean correlation with } \\
\text { other scales }\end{array}$ \\
\hline duration & 7 & 0.56 & 0.41 \\
pedagogical & 7 & 0.80 & 0.49 \\
aspects & & & \\
curriculum & 7 & 0.64 & 0.49 \\
innovation & 7 & 0.80 & 0.47 \\
\hline
\end{tabular}

\subsection{Research objective 2}

To assess the perceptions of teacher trainees towards the two-year teacher education programme in terms of duration, pedagogy, curriculum, and innovation.

The data on the four scales of the TTPAQ were collected from 200 students in two colleges who have been pursuing the 2 years B.Ed. and M.Ed. programmes. Item means and standard deviations were computed to determine the perceptions of the teacher trainees towards the two-year B.Ed. and M.Ed. programmes using the TTPAQ. The data obtained are presented in Table 3.

Table 3. Means and standard deviations for the TTPAQ

\begin{tabular}{cccc}
\hline scale name & no. of items & mean & $\begin{array}{c}\text { standard deviation } \\
\text { (SD) }\end{array}$ \\
\hline duration & 7 & 3.52 & 0.65 \\
pedagogical & 7 & 4.05 & 0.59 \\
aspects & & & \\
curriculum & 7 & 3.62 & 0.61 \\
innovation & 7 & 4.10 & 0.62 \\
\hline & $\mathbf{N}=\mathbf{2 0 0} * *$ Significant $\mathbf{~ a t ~} \mathbf{p}<\mathbf{0 . 0 1}$
\end{tabular}

From the results in Table 3 it can be seen that the mean scores of the different scales of TTPAQ ranged from 3.52 for the Duration scale to 4.10 for the Innovation scale. This shows that the mean score of TTPAQ are high which indicates that teacher trainees of the B.Ed. and M.Ed. programmes have positive perceptions towards the Duration, Pedagogical Aspects, Curriculum, and Innovation of the programme. They see a lot of scope in Pedagogical Aspects of the programme. Since the duration is long, curriculum is made in such a way that it enhances teacher trainees' skills (innovation skill) as a teacher. Students are given exposure to a wide variety of school subjects in the new curriculum, the teachers use innovative methods to teach new curriculum and most importantly, internship programmes are helpful for teacher trainees for understanding the nature of the job of a teacher. The present teacher education curriculum inculcates scientific temper, morality and democratic and social values in the minds of the teacher trainees and thereby helps to develop selfconfidence and self-reliance to face the challenges in real school environment. The Innovation scale result indicates that teacher trainees get ample opportunity to enhance their ICT skills in the teacher education programme. Reflective journal is an innovative activity that helps teacher trainees to report the progress of their leaning process. The values of standard deviations for all the TTPAQ scales is less than 1, which suggests that there are no major deviations in teacher trainees' perceptions towards the two-year teacher education programme.

\subsection{Research Objective 3}

To investigate whether gender differences exist in the perceptions of teacher trainees towards the two-year teacher education programme.

The third research question was to investigate whether gender differences exist in teacher trainees' perceptions towards the two-year teacher education programme. In the present sample of 200 students taken from 2 colleges, there were 148 (74\%) female students and $52(26 \%)$ male students who were studying in the B.Ed. and M.Ed. programmes. The mean and standard deviations for each of the female and male groups were computed followed by a test of significance of difference between means ( $\mathrm{t}$ - test for independent samples) on the four scales of the TTPAQ. The data obtained are presented in Table 4. 
Table 4. Means, standard deviations and significance of difference between means for gender differences in the teacher trainees perceptions as measured by the TTPAQ

\begin{tabular}{cccccc}
\hline scale & gender & mean & $\begin{array}{c}\text { mean } \\
\text { difference }\end{array}$ & $\begin{array}{c}\text { standard } \\
\text { deviation }\end{array}$ & t \\
\hline duration & Female & 3.58 & 0.2 & 0.66 & 1.93 \\
& Male & 3.38 & & 0.60 & \\
pedagogical & Female & 4.05 & 0.01 & 0.59 & 1.73 \\
aspects & Male & 4.04 & & 0.58 & \\
curriculum & Female & 3.62 & 0 & 0.63 & 0.40 \\
innovation & Male & 3.62 & & 0.53 & \\
& Female & 4.11 & 0.02 & 0.64 & 0.11 \\
& Male & 4.09 & & 0.54 & \\
\hline
\end{tabular}

Males: $N=52$; Females: $N=148$

From the information given in Table 4, it can be seen that none of the four scales of the TTPAQ is statistically significant. The data analysis reveals that there are no gender differences in teacher trainees towards the two-year teacher education programme. Thus, both male and female have perceived their two-year teacher education programme in a similar manner. They both believe that the duration, pedagogical aspects of the course, curriculum and innovation approach in the whole programme is beneficial for them.

\subsection{Research objective 4}

To investigate whether differences exist in the perceptions of teacher trainees towards the two-year teacher education programme between private and government colleges of education.

In order to achieve the fourth objective i.e. to investigate if there are any differences in the perceptions of teacher trainees of private $(\mathrm{N}=100)$ and government colleges $(\mathrm{N}=100)$ towards the two-year B.Ed. and M.Ed. programmes as measured by the Teacher Trainees Perception Assessment Questionnaire (TTPAQ) the means and standard deviations for each of the private and government colleges were computed followed by a test of significance of difference between means (t-test for independent samples) on the four scales of the TTPAQ. The obtained results are presented in Table 5.

Table 5. Means, standard deviations and t-test for college based differences in teacher trainees perceptions as measured by the TTPAQ

\begin{tabular}{cccccc}
\hline scale & colleges & mean & $\begin{array}{c}\text { mean } \\
\text { difference }\end{array}$ & $\begin{array}{c}\text { standard } \\
\text { deviation }\end{array}$ & t \\
\hline duration & private & 3.81 & 0.67 & 0.64 & $8.31^{* *}$ \\
& govt. & 3.14 & & 0.43 & \\
$\begin{array}{c}\text { pedagogical } \\
\text { aspects }\end{array}$ & private & 4.19 & 0.34 & 0.51 & $4.29^{* *}$ \\
& govt. & 3.85 & & 0.64 & \\
curriculum & private & 3.86 & 0.57 & 0.59 & $7.32^{* *}$ \\
& govt. & 3.29 & & 0.46 & $4.19^{* *}$ \\
innovation & private & 3.29 & 0.36 & 0.58 & \\
\hline
\end{tabular}

Government College: $N=100$; Private College: $N=100$

It can be seen from Table 5 that all the four scales of the TTPAQ, i.e. Duration with a t value of 8.31, Pedagogical Aspects with a t value of 4.29, Curriculum with a t value of 7.32 is and Innovation with t value of 4.19 are statistically significant $(p<0.01)$. In all the four scales private colleges have a higher mean score than the government colleges. This means that on the duration scale teacher trainees of private colleges are in favour of two-year teacher education programme and do not consider it to be a wastage of time. They also agree that semester system is ideal for the new teacher education programme. The pedagogical aspects scale indicates that the new teacher education programme gives students the right amount of exposure to a wide variety of school subjects and also give the teachers good chance to use innovative methods to teach the new curriculum. Curriculum scale indicates that students of private colleges were satisfied with the amount of opportunities provided by this curriculum for developing teaching competencies in student teachers. They were also able to find ample number of books and resources on various topics of the new curriculum. Data on the innovation scale indicates that the curriculum of two-year teacher education programme gives opportunities to enhance teacher trainee's ICT skills and focusses on educational technology. Pre-internship programme, field visits, and sessional work helps teacher trainees in developing their personality as a teacher and helps them in getting the practical knowledge about various aspects of being a teacher. Introduction of innovative activity like reflective journal helps teacher trainees to report the progress of their learning process in an objective manner. 


\subsection{Research objective 5}

To investigate whether differences exist in the perceptions of teacher trainees towards the-two-year teacher education programme between B.Ed. and M.Ed. classes.

In order to investigate the difference in perceptions between teacher trainees of both B.Ed. $(\mathrm{N}=140)$ and $\mathrm{M}$.Ed. $(\mathrm{N}=$ 60) programmes towards the two-year teacher education programme the means and standard deviations for each of the B.Ed. and M.Ed. classes were computed followed by a test of significance of difference between means ( $\mathrm{t}$ test for independent samples) on the four scales of the TTPAQ. The data obtained are presented in Table 6.

It can be seen from Table 6 that out of the four scales of the TTPAQ only three scales, i.e. Duration with a $t$ value of 2.21, Pedagogical Aspects with a t value of 1.98 and curriculum with a t value $1.96(\mathrm{p}<0.05)$ are statistically significant. In Duration and Curriculum scales teacher trainees of B.Ed. classes have higher mean score than the teacher trainees of M.Ed. classes and for the Pedagogical Aspects scale teacher trainees of M.Ed. classes have higher mean score than the teacher trainees of B.Ed. classes. This means that teacher trainees of B.Ed. classes feel that the duration of the programme is just right for them and semester system is ideal for them in keeping touch with the subjects since the exams are conducted every six months. Regarding curriculum, B.Ed. students feel that curriculum is not just focussed on examinations but also on skill development and the number of practice teaching lessons in the curriculum are adequate. On the other hand, teacher trainees of M.Ed. classes think that they were given exposure to a wide variety of school subjects in the new curriculum and internship programmes were helpful in understanding the ground realities of being a teacher.

Table 6. Means, standard deviations and significance of difference between means for class based differences in a Teacher Trainees Perception as measured by the TTPAQ scale

\begin{tabular}{cccccc}
\hline scale & class & mean & $\begin{array}{c}\text { mean } \\
\text { differences }\end{array}$ & $\begin{array}{c}\text { standard } \\
\text { deviation }\end{array}$ & t \\
\hline duration & B.Ed. & 3.59 & 0.21 & 0.71 & $2.21^{*}$ \\
& M.Ed. & 3.38 & & 0.49 & $1.98^{*}$ \\
pedagogical & B.Ed. & 3.99 & -0.18 & 0.60 & $1.96^{*}$ \\
aspects & M.Ed. & 4.17 & & 0.55 & \\
curriculum & B.Ed. & 3.68 & 0.18 & 0.66 & 1.71 \\
& M.Ed. & 3.50 & & 0.45 & 0.62 \\
\hline
\end{tabular}

B.Ed: $N=140 ;$ M.Ed : $N=60$

\subsection{Educational implications of the study}

Based on the results of the present study the following important implications can be offered:

(1) The new teacher education programme may enable the teacher trainees to develop enhanced teaching competencies.

(2) For the first time a comparative study of the teacher trainees of the private and government colleges of education using the Teacher Trainees Assessment Questionnaire (TTPAQ) has been done. The results have shown that TTPAQ can be considered a reliable tool to be used at the teacher education level to study the perceptions of teacher trainees.

(3) The study is likely to provide information to teacher educators regarding the changes in the curriculum which can be brought about to improve the teaching-learning process.

(4) The outcomes of the study can provide information about the Duration, Pedagogical Aspects, Curriculum and Innovation aspect of the two-year teacher education programme at the B.Ed. and M.Ed. level. This can help policy makers to further improve the programmes and make them skill oriented.

\section{Conclusion}

A major contribution of the present study is the reliability and validity of questionnaire (TTPAQ) for assessing the perceptions of teacher trainees of B.Ed. and M.Ed. programmes towards the two-year teacher education programme. In this research we have examined the perception of teacher trainees towards sudden stretch of B.Ed. and M.Ed. programmes from one years to two years. This shows that teacher trainees are in favour of the duration of the programme and it is not wastage of their time according to them. They also agree that semester system is ideal for the new teacher education programme. It provides greater scope for development of sound knowledge on different areas i.e. content knowledge, 
knowledge on teaching-learning methodologies and knowledge on pedagogy of teaching learning among the teacher trainees. The implications for teachers as outlined in this study suggest new teacher education programme may enable teacher trainees in teaching competencies and improves teacher trainees and teacher educators relationship, ultimately affecting the overall quality of the teaching learning process. The findings of this research can be broadly applied to the study of the teacher trainees' perceptions towards the teacher education programme in areas other than teacher educators by researchers and practitioners of education.

\section{References}

[1] NCTE. B.Ed. New regulations, The Gazette of India: Extraordinary [Part III-Sec.4], 2014.

[2] Kothari DS. Education commission (1964-66). Ministry of Education. New Delhi. 1964.

[3] Justice Verma Commission. Teacher education. New Delhi: Government of India, 2012.

[4] Pillai M. The impact of practicing schools on quality teaching practice of teacher trainees. 2004. Available from https://www.academia.edu/8604304/ [Accessed $8^{\text {th }}$ March 2019].

[5] Gopinathan S. Challenging the paradigm: Notes on developing an indigenized teacher education curriculum. Improving Schools. 2006; 9 (3): 261-272.

[6] Halakatti V, Mundasnavar M. In-service teacher education inevitable for qualityeducationin the 21 st century. Edutracks. 2009; 9(3): 22-25.

[7] Kalra M, Baveja B. Student teachers'thinking about knowledge, learning and learners in India. University of Delhi. New Delhi, India, 2012.

[8] Sao S, Behera SK. Student-teachers' attitude towards Two-Year B.Ed. programme with reference to NCTE regulation. Pedagogy of Learning. 2016; 2(3): 09-24.

[9] Khan M. Implementation of two-year B.Ed. programme: Issues and concerns. Paripex-Indian Journal of Research. 2017; 6(3): 573-576.

[10] Fraenkel JR, Wallen NE. How to Design and Evaluate Research in Education. Boston, MA: McGraw-Hill; 2000.

[11] De Vellis RF. Scale Development: Theory and Application. Newbury Park: Sage Publications; 1991. 